Article

\title{
Effect of Saponification Condition on the Morphology and Diameter of the Electrospun Poly(vinyl acetate) Nanofibers for the Fabrication of Poly(vinyl alcohol) Nanofiber Mats
}

\author{
Seong Baek Yang ${ }^{1}$, Jong Won Kim ${ }^{2, *}$ and Jeong Hyun Yeum ${ }^{1, *}$ \\ 1 Department of Bio-fibers and Materials Science, Kyungpook National University, Daegu 41566, Korea; \\ ysb@knu.ac.kr \\ 2 Department of Textile Engineering \& Technology, Yeungnam University, Gyeongsan 38541, Korea \\ * Correspondence: kjwfiber@ynu.ac.kr (J.W.K.); jhyeum@knu.ac.kr (J.H.Y.); Tel.: +82-53-810-3893 (J.W.K.); \\ +82-53-950-5739 (J.H.Y.); Fax: +82-53-950-6744 (J.H.Y)
}

Academic Editor: Hsing-Lin Wang

Received: 8 September 2016; Accepted: 17 October 2016; Published: 21 October 2016

\begin{abstract}
Novel poly(vinyl alcohol) (PVA) nanofiber mats were prepared for the first time through heterogeneous saponification of electrospun poly(vinyl acetate) (PVAc) nanofibers. The effect of varying the saponification conditions, including temperature, time, and concentration of the alkaline solution, on the morphology of the saponified PVA fibers were evaluated by field-emission scanning electron microscopy. At $25^{\circ} \mathrm{C}$, the saponified PVA fibers exhibited a broad diameter distribution. The average fiber diameter, however, was found to decrease with increasing saponification temperature. When the saponification time was increased from 6 to $30 \mathrm{~h}$, the average fiber diameter decreased gradually from 1540 to $1060 \mathrm{~nm}$. In addition, the fiber diameter and morphology were also affected by the concentration of the alkaline saponification solution. The most optimal conditions for fabrication of thin, uniform, and smooth PVA nanofibers corresponded to an alkaline solution containing $10 \mathrm{~g}$ each of $\mathrm{NaOH}, \mathrm{Na}_{2} \mathrm{SO}_{4}$, and methanol per $100 \mathrm{~g}$ of water, a temperature of $25^{\circ} \mathrm{C}$, and a saponification time of $24 \mathrm{~h}$.
\end{abstract}

Keywords: electrospinning; heterogeneous saponification; poly(vinyl alcohol); poly(vinyl acetate); nanofiber mats

\section{Introduction}

Unlike most vinyl polymers, poly(vinyl alcohol) (PVA) cannot be prepared by direct polymerization of the corresponding monomer as a result of its keto-enol tautomerism [1,2]. Instead, PVA is synthesized by polymerizing vinyl acetate, followed by conversion of the resulting poly(vinyl acetate) (PVAc) into PVA through saponification [3-5]. PVA nanofibers are currently used as drug [6] and protein carriers [7] as well as nanocomposite electrospun fiber matrices for antibacterial treatments [8], tissue engineering [9], and other biomedical applications [10]. Several research groups have used heterogeneous saponification to manufacture PVA from PVAc. For example, Lee et al. prepared PVA/PVAc microspheres through heterogeneous surface saponification of PVAc microspheres and investigated the rate of saponification in the presence of various ions [11]. In another study, Lee et al. developed a novel method of manufacturing syndiotactic PVA/poly(vinyl pivalate/vinyl acetate) microspheres through heterogeneous saponification and also investigated the effect of their initial diameter on the degree of saponification (DS) of PVA [12]. A simple, continuous heterogeneous saponification method was applied by Lyoo et al. to obtain high-molecular-weight PVA from suspension-polymerized PVAc, and the effect of saponification time and temperature on their DS was 
investigated [13]. In addition, the same group also prepared PVA/PVAc shell/core microspheres of different sizes by surface saponification of emulsion-polymerized PVAc [14].

In this study, heterogeneous saponification is used to convert PVAc into PVA. Previously, we reported the synthesis of PVAc/PVA/montmorillonite (MMT) nanocomposite microspheres by suspension polymerization and heterogeneous saponification and described the effect of the MMT presence on the PVAc polymerization and saponification rates [15]. In another report, we examined a novel method of manufacturing PVA/clay microspheres through suspension polymerization and heterogeneous saponification, where the formation of fully saponified nanocomposite microspheres was confirmed by proton nuclear magnetic resonance $\left({ }^{1} \mathrm{H}-\mathrm{NMR}\right)$ spectroscopy [16]. Many researchers have reported PVA nanofibers prepared by electrospinning of a PVA solution. Bai et al. demonstrated an easy and effective electrospinning technique for fabricating PVA/Au composite nanofibers [17]. In another study, the preparation of PVA/multi-walled carbon nanotubes was explored [18]. The effect of molecular weight on the fiber structure of electrospun PVA has been investigated by Koski et al. [19]. The preparation of electrospun PVA mats and their morphologies were studied by Zhang et al. [20], while the effect of $\mathrm{pH}$ on the morphology and the average diameter of electrospun PVA fibers was discussed by Son et al. [21]. Many researchers have also described cell propagation in modified nanofibers. Zhang et al. [22] examined nanofiber-modified surface directed cell movement and arrangement in a microsystem. The effect of the nanofiber arrangement in electrospun nanofibrous scaffolds on cell growth and elastin appearance of muscle cells was reported by Zhong et al. [23]. Surface-modified nanofibers have some benefits as a result of the larger specific surface area compared to smooth surface nanofibers. Recently, our group succeeded in converting PVAc nanofibers into PVA nanofibers using heterogeneous saponification technique. However, this work reported only the preparation of PVA nanofibers, without examining the effect and the most optimal nature of saponification conditions [24]. The present study aims to fabricate PVA nanofiber mats with a potential application in bio-materials, for example in animal testing, cell proliferation, and cell culture, and to investigate further the nanofiber formation.

In this work, we demonstrate an inexpensive technique for preparing PVA nanofiber mats through heterogeneous saponification of electrospun PVAc nanofibers, without the need for a PVA solution. In addition, the effect of saponification conditions on the morphology and diameter of the electrospun saponified PVAc nanofibers is investigated. The results showed that the optimal conditions for fabricating thin, uniform, and smooth saponified PVA nanofibers corresponded to an alkaline solution containing $\mathrm{NaOH}(10 \mathrm{~g}), \mathrm{Na}_{2} \mathrm{SO}_{4}(10 \mathrm{~g})$, and methanol $(\mathrm{MeOH}, 10 \mathrm{~g})$ per $100 \mathrm{~g}$ of water, at a temperature of $25^{\circ} \mathrm{C}$, and a saponification time of $24 \mathrm{~h}$.

\section{Materials and Methods}

\subsection{Materials}

Vinyl acetate (VAc) (Sigma-Aldrich, St. Louis, MO, USA) was purified by treatment with an aqueous solution of $\mathrm{NaHSO}_{4}$, followed by drying over anhydrous $\mathrm{CaCl}_{2}$ and distillation under $\mathrm{N}_{2}$ atmosphere. The PVA suspending agent with an average molecular weight of 127,000 and DS of $88 \%$ (Sigma-Aldrich) was recrystallized twice from $\mathrm{MeOH}$ before use. An aqueous alkaline solution containing $\mathrm{NaOH}$ (Duksan, Ansan, Korea), $\mathrm{Na}_{2} \mathrm{SO}_{4}$ (Duksan), and $\mathrm{MeOH}$ (Duksan) was prepared for heterogeneous saponification. Deionized water was utilized in all experiments.

\subsection{Preparation of Poly(vinyl acetate) (PVAc) by Suspension Polymerization of vinyl acetate (VAc)}

To prepare PVAc, the PVA suspending agent was dissolved in continuously stirred distilled water $(120 \mathrm{~mL})$ in a $250 \mathrm{~mL}$ reactor equipped with a condenser. The VAc monomer and $2,2^{\prime}$-azobis (2,4-dimethylvaleronitrile) (ADMVN) initiator were degassed and added to this mixture at a polymerization temperature of $15^{\circ} \mathrm{C}$, and the reaction temperature was increased to $60^{\circ} \mathrm{C}$. After a specified time period elapsed, the reaction was stopped and the resulting mixture was left for $1 \mathrm{~h}$ 
to isolate the obtained spherical PVAc particles. After a prearranged time has elapsed, the reaction mixture was cooled and set aside for 1 day to allow the precipitation and partition of the PVAc particles. After this time, the accumulated PVAc particles were washed with warm water. Gravimetric analysis confirmed the successful conversion of the VAc monomer [16]. An overview of the polymerization conditions is provided in Table 1.

Table 1. Reaction conditions for the suspension polymerization of VAc.

\begin{tabular}{cc}
\hline Condition & Value \\
\hline Type of initiator & ADMVN \\
Type of suspending agent & PVA \\
Initiator concentration & $0.0001 \mathrm{~mol} / \mathrm{mol}$ of VAc \\
Suspending agent concentration & $1.5 \mathrm{~g} / \mathrm{dL}$ of water \\
VAc/water & $0.5 \mathrm{~L} / \mathrm{L}$ \\
rpm & 400 \\
Temperature & $60{ }^{\circ} \mathrm{C}$ \\
\hline
\end{tabular}

ADMVN: 2,2'-azobis(2,4-dimethylvaleronitrile); PVA: poly(vinyl alcohol); VAc: Vinyl acetate.

\subsection{Electrospinning of PVAc Nanofibers}

In order to prepare an electrospinning solution, the manufactured PVAc was dissolved over $2 \mathrm{~h}$ in $\mathrm{MeOH}$ at room temperature, with continuous stirring. All experiments in this work employed PVAc at $15 \mathrm{wt} \%$ (a concentration based on the weight of the solution). During electrospinning, a high voltage of $15 \mathrm{kV}$ (CPS-60K02, VIT, Chungpa EMT Co., Ltd., Seoul, Korea) was applied to an alligator clip attached to a syringe needle containing $30 \mathrm{~mL}$ of the PVAc solution. The solution was transported to the blunt needle using a syringe pump to control the flow rate. An electrically grounded piece of $\mathrm{Al}$ foil, placed at a vertical distance of $15 \mathrm{~cm}$ from the needle tip, was used to collect the obtained fibers, which were subsequently air-dried and removed from the Al foil before saponification. These spinning conditions were found to be the most optimal for manufacturing of PVAc mats.

\subsection{Heterogeneous Saponification of PVAc Nanofibers}

To convert the PVAc nanofibers into PVA nanofibers, heterogeneous saponification was performed in a flask equipped simultaneously with a thermocouple, a reflux condenser, a dropping funnel, and a stirring device. An alkaline solution for the saponification process was prepared by adding $\mathrm{NaOH}$ (5-10 g), $\mathrm{Na}_{2} \mathrm{SO}_{4}(5-10 \mathrm{~g})$, and $\mathrm{MeOH}(5-10 \mathrm{~g})$ to deionized water (100 g). In our previous work, we found that the optimum composition of the saponification solution consists of $\mathrm{NaOH}(10 \mathrm{~g}), \mathrm{Na}_{2} \mathrm{SO}_{4}$ $(10 \mathrm{~g})$, and $\mathrm{MeOH}(10 \mathrm{~g})$ added to deionized water $(100 \mathrm{~g})$ [24]. If more than $10 \mathrm{~g}$ of $\mathrm{NaOH}$ were used, the saponified PVA nanofibers exhibited a yellow color. Therefore, we excluded such harsh conditions from this study (i.e., above $10 \mathrm{~g}$ of $\mathrm{NaOH}$ ). To investigate the effect of changing the saponification solution, we specifically tested a solution prepared using $\mathrm{NaOH}(5 \mathrm{~g}), \mathrm{Na}_{2} \mathrm{SO}_{4}(5 \mathrm{~g})$, and $\mathrm{MeOH}(5 \mathrm{~g})$ in deionized water $(100 \mathrm{~g})$. Subsequently, the electrospun PVAc fibers were slowly added to the prepared alkaline solution at various temperatures $\left(25,35\right.$, and $\left.45^{\circ} \mathrm{C}\right)$, employing moderate stirring. The PVA nanofibers were formed from the PVAc fibers after different saponification times $(6,12,18,24$, and $30 \mathrm{~h})$. The obtained alkaline solution mixture was poured into cold water for $1 \mathrm{~min}$ in order to precipitate the resulting PVA nanofiber mats, which were subsequently washed several times with deionized water and dried under vacuum for $24 \mathrm{~h}$. The complete saponification conditions are recorded in Table 2. 
Table 2. The reagents and conditions employed in the heterogeneous saponification of PVAc nanofibers and the resulting degree of saponification. (DS: Degree of saponification).

\begin{tabular}{cccccccc}
\hline Figure & $\mathbf{N a O H}(\mathbf{g})$ & $\mathbf{N a}_{2} \mathbf{S O}_{\mathbf{4}} \mathbf{( g )}$ & $\mathbf{M e O H}(\mathbf{g})$ & $\mathbf{H}_{\mathbf{2}} \mathbf{O}(\mathbf{g})$ & Temparature $\left({ }^{\circ} \mathbf{C}\right)$ & Time (h) & DS $(\%)$ \\
\hline Figure 2A & 10 & 10 & 10 & 100 & 25 & 12 & 70.8 \\
Figure 2B & 10 & 10 & 10 & 100 & 35 & 12 & 98.17 \\
Figure 2C & 10 & 10 & 10 & 100 & 45 & 12 & 99.72 \\
Figure 3A & 10 & 10 & 10 & 100 & 25 & 6 & 0 \\
Figure 3B & 10 & 10 & 10 & 100 & 25 & 12 & 70.8 \\
Figure 3C & 10 & 10 & 10 & 100 & 25 & 18 & 79.14 \\
Figure 3D & 10 & 10 & 10 & 100 & 25 & 24 & 95.64 \\
Figure 3E & 10 & 10 & 10 & 100 & 25 & 30 & 99.93 \\
Figure 4A & 5 & 5 & 5 & 100 & 25 & 24 & 45.8 \\
Figure 4B & 7.5 & 5 & 5 & 100 & 25 & 24 & 80.85 \\
Figure 4C & 5 & 7.5 & 5 & 100 & 25 & 24 & 88.86 \\
Figure 4D & 5 & 5 & 7.5 & 100 & 25 & 24 & 69.64 \\
Figure 4E & 10 & 5 & 5 & 100 & 25 & 24 & 61.08 \\
Figure 4F & 5 & 10 & 5 & 100 & 25 & 24 & 68.94 \\
Figure 4G & 5 & 5 & 10 & 100 & 25 & 24 & 59.26 \\
\hline
\end{tabular}

\subsection{Characterization}

The molecular weights of the electrospun PVA nanofibers and the fully saponified PVA nanofibers were determined using gel permeation chromatography (GPC, Waters, Milford, MA, USA) [25]. The surface morphology of the saponified PVA nanofiber mats was studied using field-emission scanning electron microscopy (FE-SEM, SU8220, Hitachi, Tokyo, Japan), and their DS values were determined using a ${ }^{1} \mathrm{H}-\mathrm{NMR}$ spectrometer (AVANCE III 500, Bruker, Karlsruhe, Germany). A Fourier transform infrared (FT-IR) spectrometer (Frontier, Perkin Elmer, Waltham, MA, USA) was utilized to measure the conversion of PVAc nanofibers to PVA nanofibers. Fiber diameters were evaluated from the obtained FE-SEM images using the Photoshop CS 7 software. The analysis examined at least 20 different fibers and 100 different randomly selected segments from each image. The tensile strength was measured using the ZWICK Z005 testing machine (Zwick GmbH, Ulm, Germany).

\section{Results and Discussion}

Owing to the various advantages of PVA polymers, many research groups have attempted to fabricate electrospun PVA bulk nanofiber mats. In this work, we have prepared for the first time saponified PVA nanofiber mats from PVAc nanofibers through heterogeneous saponification. Figure 1 shows a schematic illustration of the heterogeneous saponification process employed in the synthesis of PVA nanofiber mats from PVAc nanofibers. The morphology of the saponified PVA nanofiber mats was found to vary depending on the different saponification conditions, such as the temperature, time, and the concentration of the saponification solution (i.e., the alkaline solution).

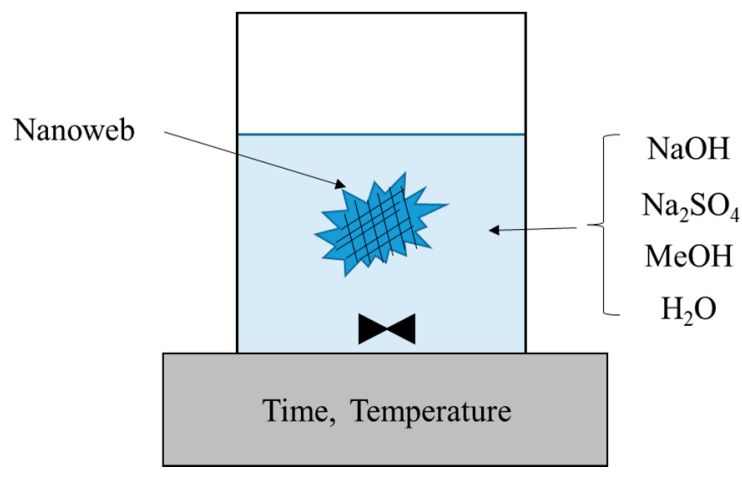

Figure 1. Schematic illustration of the heterogeneous saponification process employed for manufacturing of PVA nanofiber mats. 
Figure 2 shows the FE-SEM images of the PVA nanofiber mats produced by heterogeneous saponification of PVAc nanofibers for $12 \mathrm{~h}$ at different temperatures $\left(25,35\right.$, and $\left.45^{\circ} \mathrm{C}\right)$, employing an alkaline solution containing $10 \mathrm{~g}$ each of $\mathrm{NaOH}, \mathrm{Na}_{2} \mathrm{SO}_{4}$, and $\mathrm{MeOH}$ added to $100 \mathrm{~g}$ of $\mathrm{H}_{2} \mathrm{O}$. We found that $25^{\circ} \mathrm{C}$ was the optimal temperature for obtaining thin and uniform saponified PVA nanofibers with a smooth surface. Figure 3 presents the FE-SEM images of PVA nanofibers produced by heterogeneous saponification of PVAc nanofibers at various times $(6,12,18,24$, and $30 \mathrm{~h})$, at a temperature of $25^{\circ} \mathrm{C}$, and a constant alkaline solution concentration corresponding to $10 \mathrm{~g}$ of $\mathrm{NaOH}, 10 \mathrm{~g}$ of $\mathrm{Na}_{2} \mathrm{SO}_{4}$, and $10 \mathrm{~g}$ of $\mathrm{MeOH}$ per $100 \mathrm{~g}$ of $\mathrm{H}_{2} \mathrm{O}$. The obtained results indicate that the saponification time affects the fiber morphology significantly. Specifically, comparatively smooth, thin, and uniform saponified PVA fibers with small diameter were easily obtained after $24 \mathrm{~h}$ saponification time (Figure 3D). In contrast, such fibers were not observed at shorter saponification times of 6 or $18 \mathrm{~h}$ (see Figure 3A,C, respectively). Furthermore, rough surface fibers with a small diameter were produced when the saponification time was increased to $30 \mathrm{~h}$ (Figure 3E).

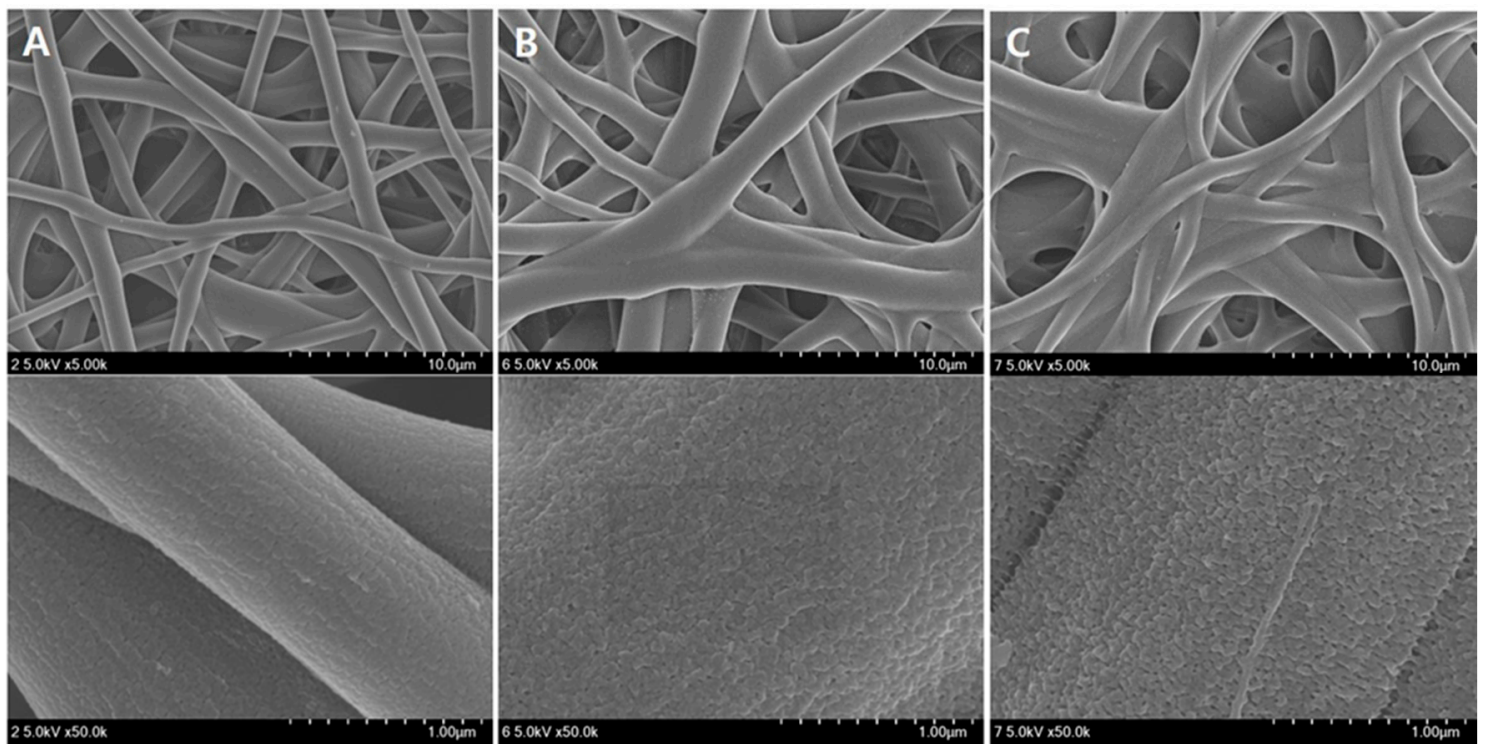

Figure 2. Field emission scanning electron microscope (FE-SEM) images of saponified PVA nanofiber mats obtained at different temperatures: (A) $25^{\circ} \mathrm{C}$; (B) $35^{\circ} \mathrm{C}$; and (C) $45^{\circ} \mathrm{C}$. The quantities of the reagents in the saponification solution $\left(\mathrm{NaOH}=10 \mathrm{~g}, \mathrm{Na}_{2} \mathrm{SO}_{4}=10 \mathrm{~g}, \mathrm{MeOH}=10 \mathrm{~g}\right.$, and $\mathrm{H}_{2} \mathrm{O}=100 \mathrm{~g}$ ) and the reaction time $(12 \mathrm{~h})$ were kept constant.
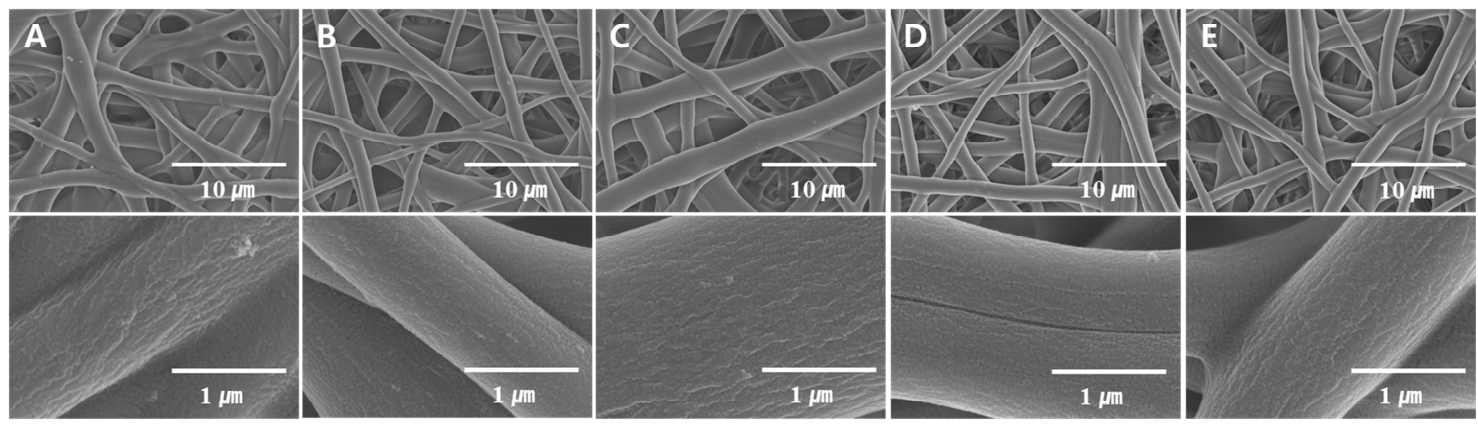

Figure 3. FE-SEM images of saponified PVA nanofiber mats obtained at different saponification times: (A) $6 \mathrm{~h}$; (B) $12 \mathrm{~h}$; (C) $18 \mathrm{~h}$; (D) $24 \mathrm{~h}$; and (E) $30 \mathrm{~h}$. The quantities of the reagents in the saponification solution $\left(\mathrm{NaOH}=10 \mathrm{~g}, \mathrm{Na}_{2} \mathrm{SO}_{4}=10 \mathrm{~g}, \mathrm{MeOH}=10 \mathrm{~g}\right.$, and $\left.\mathrm{H}_{2} \mathrm{O}=10 \mathrm{~g}\right)$ and the reaction temperature were kept constant $\left(25^{\circ} \mathrm{C}\right)$. 
Next, a series of experiments were conducted using different concentrations of saponification solution reagents and a constant temperature and time of $25^{\circ} \mathrm{C}$ and $24 \mathrm{~h}$, respectively. The results presented in Figure 4 indicate that the fiber morphology depends strongly on the ratio of the saponification solutions constituents $\left(\mathrm{NaOH}, \mathrm{Na}_{2} \mathrm{SO}_{4}\right.$, and $\left.\mathrm{MeOH}\right)$. After a careful comparison of the FE-SEM images displayed in Figure 4, we were able to conclude that preparation of saponified PVA nanofibers at low concentrations of $\mathrm{NaOH}$ and $\mathrm{Na}_{2} \mathrm{SO}_{4}$ is not possible (see Figure $4 \mathrm{~A}, \mathrm{C}, \mathrm{D}, \mathrm{G}$ ). On the other hand, the saponified fibers could be easily obtained at high concentrations of $\mathrm{NaOH}$ and $\mathrm{Na}_{2} \mathrm{SO}_{4}$ (Figure 4E,F). The presence of $\mathrm{MeOH}$ also affected the morphology of the saponified PVA nanofibers significantly (Figure 4A,D,G). While saponified PVA was unable to retain its fibrous morphology at high $\mathrm{MeOH}$ concentrations (Figure 4D,G), this effect of $\mathrm{MeOH}$ addition on the fiber morphology became insignificant at higher concentrations of $\mathrm{NaOH}$ and $\mathrm{Na}_{2} \mathrm{SO}_{4}$ (Figure 3D).

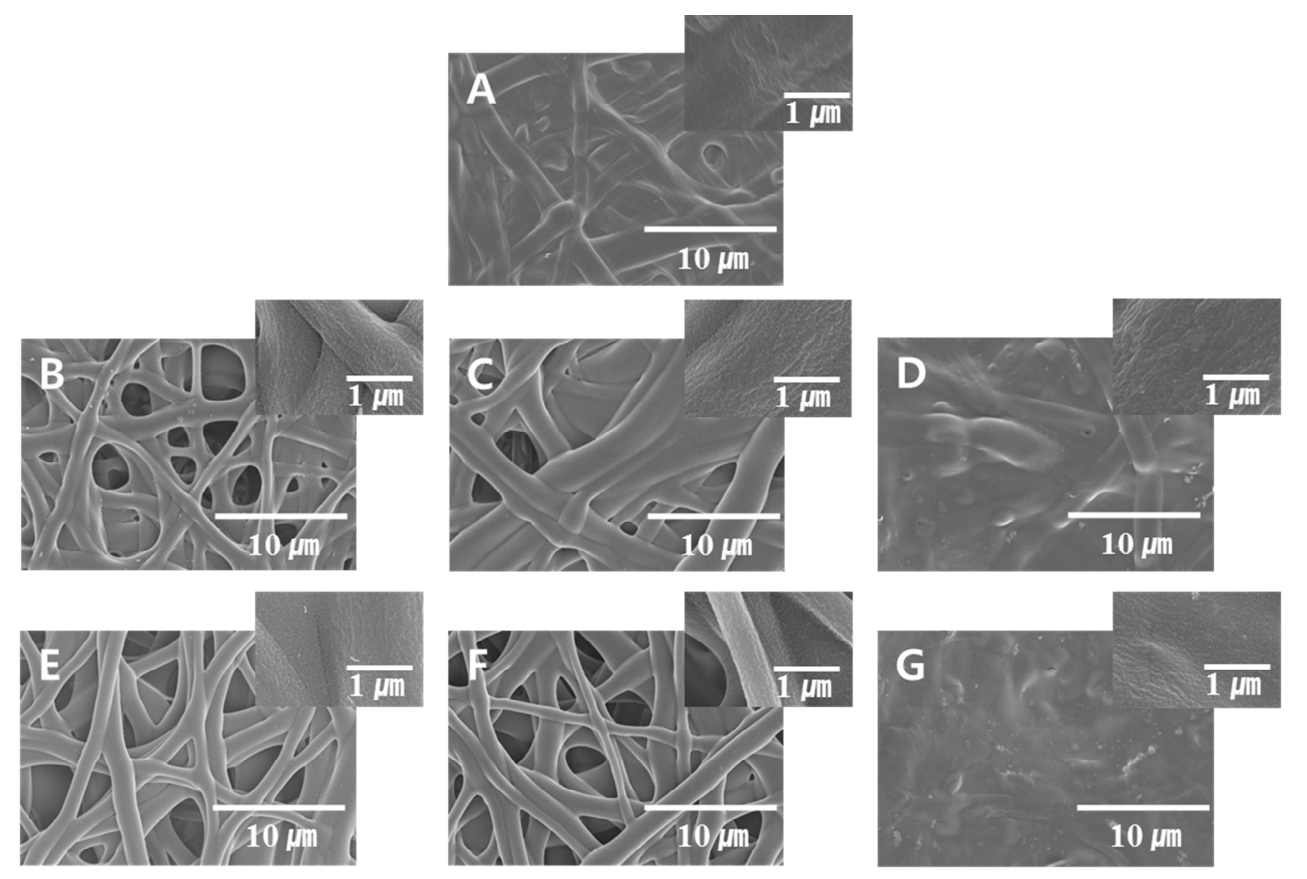

Figure 4. FE-SEM images of saponified PVA nanofiber mats obtained using saponification solution prepared using different respective quantities of $\mathrm{NaOH}, \mathrm{Na}_{2} \mathrm{SO}_{4}$, and $\mathrm{MeOH}$ per $100 \mathrm{~g}$ of $\mathrm{H}_{2} \mathrm{O}$ : (A) 5, 5, and $5 \mathrm{~g}$; (B) 7.5, 5, and $5 \mathrm{~g}$; (C) 5, 7.5, and $5 \mathrm{~g}$; (D) 5, 5, and $7.5 \mathrm{~g}$; (E) 10, 5, and $5 \mathrm{~g}$; (F) 5, 10, and $5 \mathrm{~g}$; and (G) 5, 5, and $10 \mathrm{~g}$. The saponification temperature and time were kept constant at $25^{\circ} \mathrm{C}$ and $24 \mathrm{~h}$, respectively.

The fiber diameter distributions for the saponified PVA nanofibers produced at different saponification temperatures are shown in Figure 5. The obtained data revealed a decrease in the average fiber diameter with increasing saponification temperature. Large amounts of thin fibers with diameters below $1000 \mathrm{~nm}$ were observed at a saponification temperature of $45^{\circ} \mathrm{C}$. The fiber arrangement in samples prepared at this temperature, however, was not regular (Figure 5C). In contrast, regularly-arranged fibers with an average diameter of $1350 \mathrm{~nm}$ were obtained at $25^{\circ} \mathrm{C}$ (Figure 5A). A narrow fiber diameter distribution was observed at the higher temperature of $45^{\circ} \mathrm{C}$, while at the lower temperature of $25^{\circ} \mathrm{C}$, the fiber diameter exhibited a broad distribution. Increasing the temperature (and thus the saponification rate) promotes the conversion of PVAc into PVA, which in turn stimulates the formation of thinner fibers since the PVA species formed during saponification can be better dissolved in the aqueous solution. The effect of saponification time on the diameter distribution of the saponified PVA nanofibers is shown in Figure 6. The diameter of the saponified PVA nanofibers was found to gradually decrease from 1540 to $1060 \mathrm{~nm}$ with increasing saponification time from 6 to $30 \mathrm{~h}$. The longer saponification times increase the dissolution rate for the PVA surface 
layers in aqueous solutions, thereby decreasing the resulting fiber diameter (Figure 6E). These smaller diameter fibers are, however, characterized by a rough surface (Figure 3E). Therefore, the most optimal saponification time for the formation of PVAc nanofibers was found to be $24 \mathrm{~h}$, which produces an average fiber diameter of $1150 \mathrm{~nm}$ (Figure 6D). Varying the concentrations of reagents in the saponification solution was also found to change the fiber diameter, as shown in Figure 7. With a saponification solution employing concentrations that correspond to $5 \mathrm{~g}$ of $\mathrm{NaOH}, 5 \mathrm{~g}$ of $\mathrm{Na}_{2} \mathrm{SO}_{4}$, and $5 \mathrm{~g}$ of $\mathrm{MeOH}$ per $100 \mathrm{~g}$ of $\mathrm{H}_{2} \mathrm{O}$, the obtained fibers were essentially affixed to each other, and their average diameter was equal to $1520 \mathrm{~nm}$ (Figure 7A). However, the fiber morphology changed when the concentration of $\mathrm{NaOH}$ was increased to $10 \mathrm{~g}$ per $100 \mathrm{~g}$ of $\mathrm{H}_{2} \mathrm{O}$. Specifically, the fiber structure changed from the united morphology to a segregated one, thus decreasing the corresponding fiber diameter (Figure 7C). On the other hand, the average fiber diameter obtained using $7.5 \mathrm{~g}$ of $\mathrm{Na}_{2} \mathrm{SO}_{4}$ (Figure 7D) was greater than that produced at $10 \mathrm{~g}$ of $\mathrm{Na}_{2} \mathrm{SO}_{4}$ (Figure 7E).
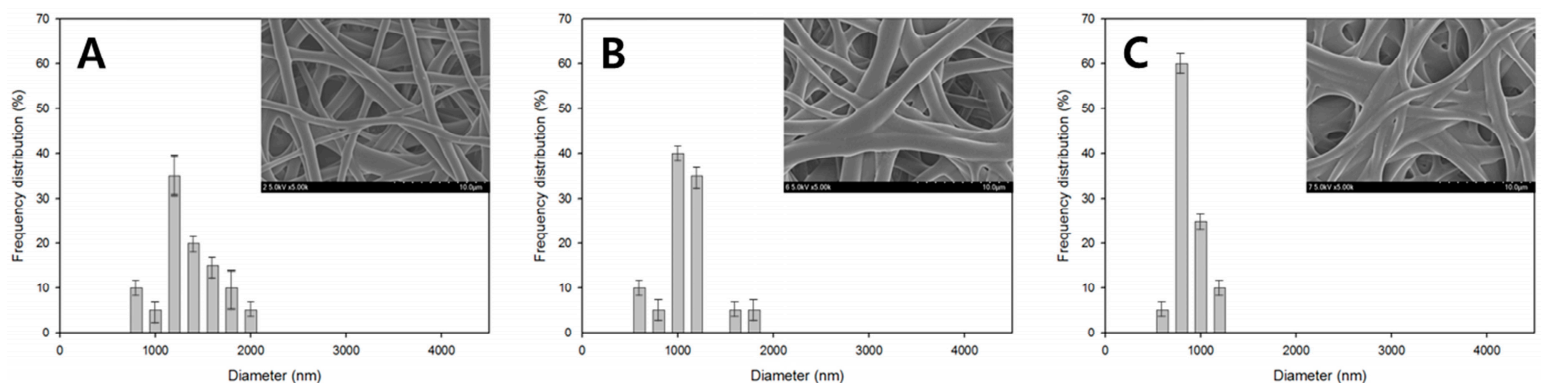

Figure 5. Fiber diameter histogram plots and FE-SEM images for saponified PVA nanofiber mats obtained at different saponification temperatures: (A) $25^{\circ} \mathrm{C}$; (B) $35^{\circ} \mathrm{C}$; and (C) $45^{\circ} \mathrm{C}$. The saponification solution contained $\mathrm{NaOH}(10 \mathrm{~g}), \mathrm{Na}_{2} \mathrm{SO}_{4}(10 \mathrm{~g})$, and $\mathrm{MeOH}(10 \mathrm{~g})$ in $\mathrm{H}_{2} \mathrm{O}(100 \mathrm{~g})$ in each case. The time was kept constant at $12 \mathrm{~h}$.
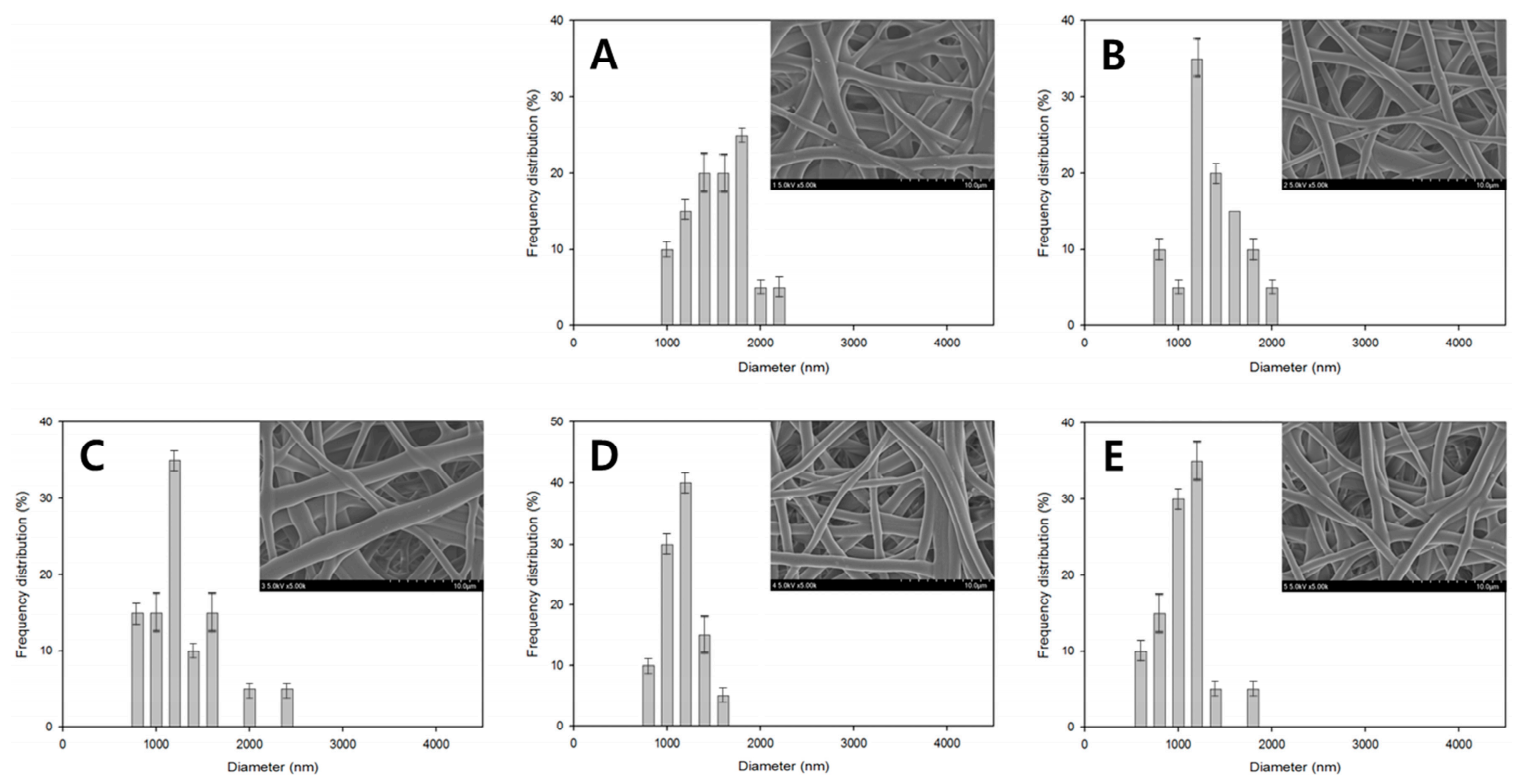

Figure 6. Fiber diameter histogram plots and FE-SEM images for saponified PVA nanofiber mats obtained at different saponification times: (A) $6 \mathrm{~h}$; (B) $12 \mathrm{~h}$; (C) $18 \mathrm{~h}$; (D) $24 \mathrm{~h}$; and (E) $30 \mathrm{~h}$. The saponification solution was prepared using the following reagents: $\mathrm{NaOH}(10 \mathrm{~g}), \mathrm{Na}_{2} \mathrm{SO}_{4}(10 \mathrm{~g})$, and $\mathrm{MeOH}(10 \mathrm{~g})$ per $100 \mathrm{~g}$ of $\mathrm{H}_{2} \mathrm{O}$. The temperature was kept constant at $25^{\circ} \mathrm{C}$. 

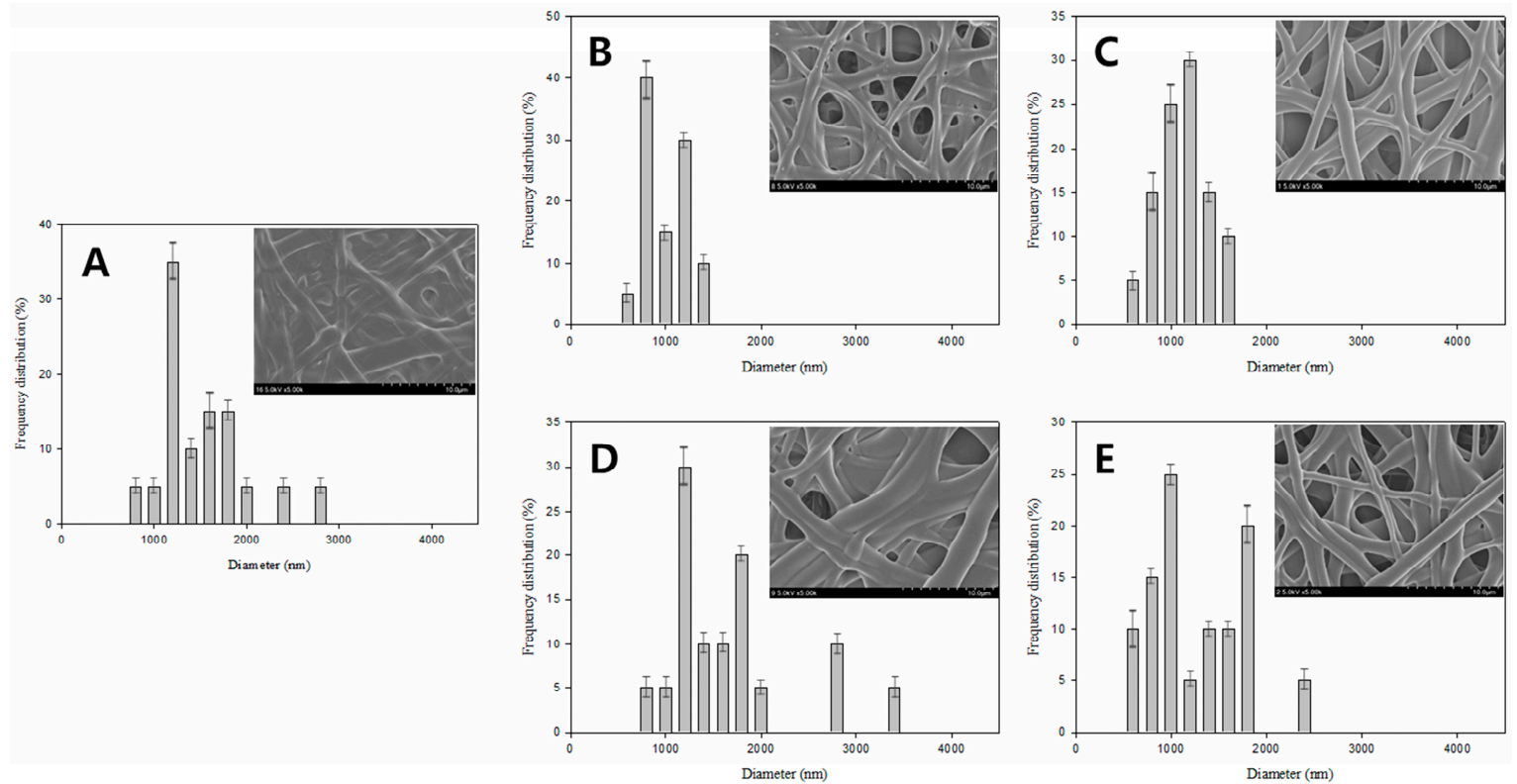

Figure 7. Fiber diameter histogram plots and FE-SEM images for saponified PVA nanofiber mats obtained using a saponification solution prepared with different respective quantities of $\mathrm{NaOH}, \mathrm{Na}_{2} \mathrm{SO}_{4}$, and $\mathrm{MeOH}$ per $100 \mathrm{~g}$ of $\mathrm{H}_{2} \mathrm{O}$ : (A) 5, 5, and $5 \mathrm{~g}$; (B) 7.5, 5, and $5 \mathrm{~g}$; (C) 10, 5, and $5 \mathrm{~g}$; (D) 5, 7.5, and $5 \mathrm{~g}$; and (E) 5, 10, and $5 \mathrm{~g}$. The saponification time and temperature were kept constant at $24 \mathrm{~h}$ and $25^{\circ} \mathrm{C}$, respectively.

The dependence of DS on the saponification temperature is shown in Figure 8A. The obtained DS value was much higher at $45{ }^{\circ} \mathrm{C}$ than those observed at 25 and $35{ }^{\circ} \mathrm{C}$, most likely as a result of the accelerated rate of saponification at higher temperatures [13]. The DS of PVA prepared by heterogeneous saponification exceeded $99 \%$ at a saponification temperature of $45^{\circ} \mathrm{C}$. The corresponding average fiber diameter, however, was also larger at this temperature compared to that obtained at 25 and $35^{\circ} \mathrm{C}$ (Figure 2). The dependence of DS on the saponification time at $25^{\circ} \mathrm{C}$ is plotted in Figure 8B, showing that the DS increases with increasing length of saponification time. The maximum DS for the PVA nanofibers saponified for $30 \mathrm{~h}$ exceeded $99 \%$. The effect of varying the quantity of reagents in the saponification solution (i.e., $\mathrm{NaOH}, \mathrm{Na}_{2} \mathrm{SO}_{4}$, and $\mathrm{MeOH}$ per $100 \mathrm{~g}$ of $\mathrm{H}_{2} \mathrm{O}$ ) on the DS of the saponified PVA nanofiber mats was also investigated in this work. The DS values for the saponified PVA at three different concentrations of $\mathrm{NaOH}$ are presented in Figure 9A, which shows an increase in the DS with increasing concentration of $\mathrm{NaOH}$, reaching the highest DS value at a $\mathrm{NaOH}$ content of $10 \mathrm{~g}$ per $100 \mathrm{~g}$ of water. The DS dependence on the $\mathrm{Na}_{2} \mathrm{SO}_{4}$ concentration is shown in Figure 9B. The DS value was found to increase with increasing concentration of $\mathrm{Na}_{2} \mathrm{SO}_{4}$ up to $7.5 \mathrm{~g}$ per $100 \mathrm{~g}$ of water. Further increase in concentration resulted in a decrease in the value of DS. The maximum DS value was obtained at $7.5 \mathrm{~g}$ of $\mathrm{Na}_{2} \mathrm{SO}_{4}$, however, the formation of thin saponified nanofibers was no longer possible at this particular concentration of $\mathrm{Na}_{2} \mathrm{SO}_{4}$ (Figure $4 \mathrm{C}$ ). Figure $9 \mathrm{C}$ shows the effect of changing the $\mathrm{MeOH}$ concentration on the DS of the saponified PVA nanofibers. The obtained dependence exhibits a trend similar to that observed for $\mathrm{Na}_{2} \mathrm{SO}_{4}$ (Figure $9 \mathrm{~B}$ ). The maximum DS value of over $68 \%$ is reached at a $\mathrm{MeOH}$ concentration of $7.5 \mathrm{~g}$ per $100 \mathrm{~g}$ of water (Figure 9C). The obtained fiber quality at this $\mathrm{MeOH}$ concentration, however, was not very good (Figure 4D). 

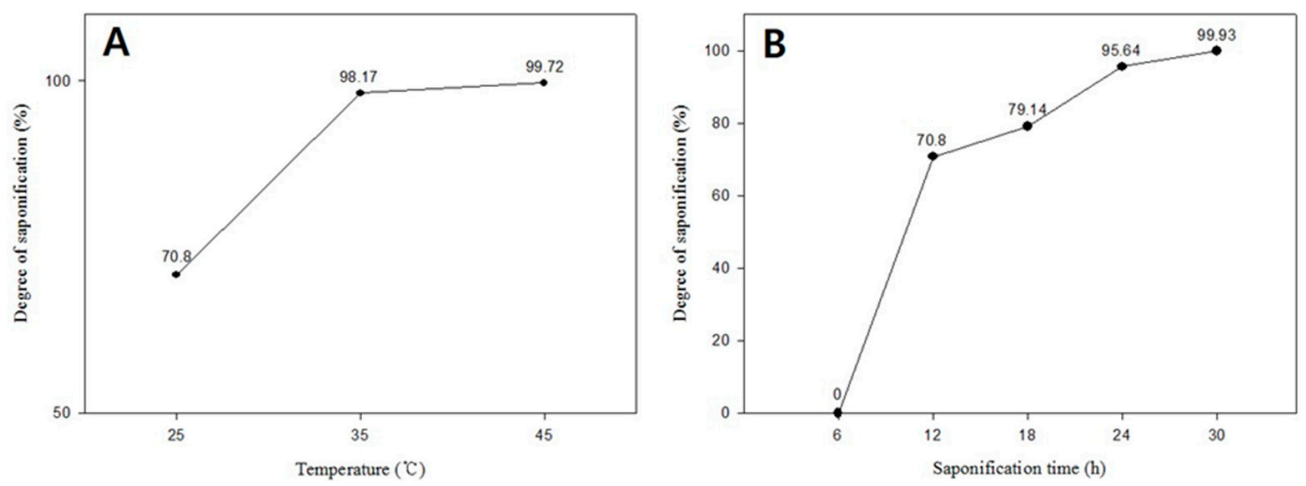

Figure 8. (A) The effect of saponification temperature on the degree of saponification (DS) (\%) of PVA saponified for $12 \mathrm{~h}$; (B) The effect of saponification time on the DS of PVA saponified at $25{ }^{\circ} \mathrm{C}$. The concentration of the saponification solution $\left(\mathrm{NaOH}, \mathrm{Na}_{2} \mathrm{SO}_{4}\right.$, and $\mathrm{MeOH}$ at $10 \mathrm{~g}$ each per $100 \mathrm{~g}$ of $\mathrm{H}_{2} \mathrm{O}$ ) was kept constant.

D.S depending on Concentration of $\mathrm{NaOH}$

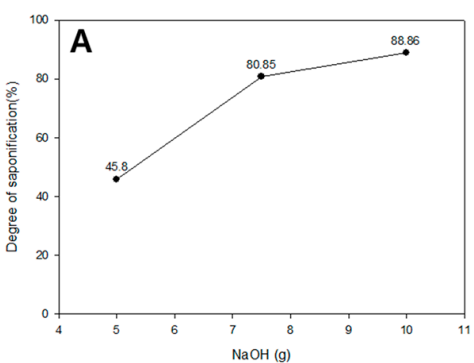

D.S depending on Concentration of $\mathrm{Na}_{2} \mathrm{SO}$

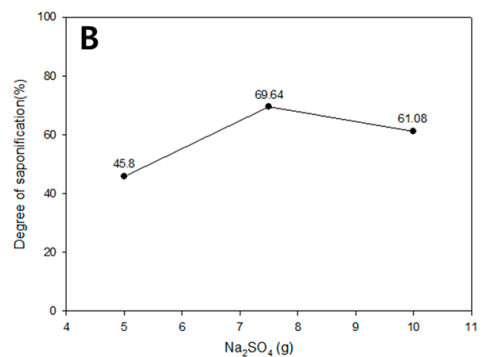

DS depending on Concentration of $\mathrm{MeOH}$

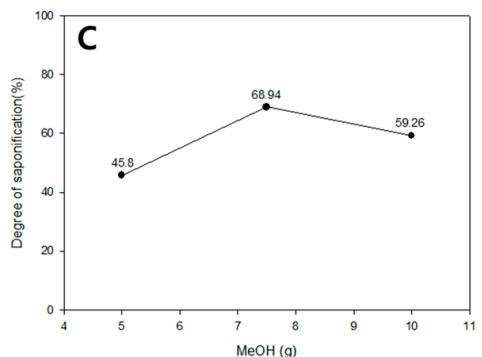

Figure 9. The effect of: (A) $\mathrm{NaOH}$; (B) $\mathrm{Na}_{2} \mathrm{SO}_{4}$; and (C) $\mathrm{MeOH}$ concentration on the DS (\%) of saponified PVA nanofibers. The saponification time and temperature were kept constant at $24 \mathrm{~h}$ and $25^{\circ} \mathrm{C}$, respectively.

In this work, all saponified samples were characterized by ${ }^{1} \mathrm{H}-\mathrm{NMR}$ and Figure $10 \mathrm{~A}$ shows the corresponding ${ }^{1} \mathrm{H}-\mathrm{NMR}$ data for the PVA nanofibers saponified for $30 \mathrm{~h}$ at $25{ }^{\circ} \mathrm{C}$. The DS of the saponified PVA nanofibers can usually be calculated from the ratio of the area of the methyl group and the area of the methylene groups present in the ${ }^{1} \mathrm{H}-\mathrm{NMR}$ spectrum (appearing at $1.74 \mathrm{ppm}$ and $1.4 \mathrm{ppm}$, respectively). However, no methyl peaks were observed in the spectra shown in Figure 10 indicating that all of the PVAc methyl groups have been converted into hydroxyl groups during saponification. Therefore, the NMR analysis confirmed that fully saponified PVA nanofibers can be obtained at saponification conditions corresponding to an alkaline solution containing $10 \mathrm{~g}$ each of $\mathrm{NaOH}, \mathrm{Na}_{2} \mathrm{SO}_{4}$, and $\mathrm{MeOH}$ per $100 \mathrm{~g}$ of $\mathrm{H}_{2} \mathrm{O}$, a temperature of $25^{\circ} \mathrm{C}$, and a saponification time of $30 \mathrm{~h}$. The FT-IR spectra of both the un-saponified PVAc and saponified PVA nanofibers were measured as shown in Figure 10B. The vibrational bands at 2923 and $2865 \mathrm{~cm}^{-1}$ correspond to $\mathrm{CH}_{3}$ asymmetric stretch and PVAc symmetric stretch, respectively [26]. The broad band viewed in the $3600-3200 \mathrm{~cm}^{-1}$ region after the saponification process can be assigned to the $\mathrm{O}-\mathrm{H}$ stretch, arising from both intermolecular and intramolecular hydrogen bonds. The vibration band in the $3000-2800 \mathrm{~cm}^{-1}$ region corresponds to the C-H alkyl group stretch [27], further demonstrating the successful formation of PVA nanofibers from PVAc nanofibers. The molecular weights of the fully saponified PVA nanofibers and general electrospun PVA nanofibers were obtained by GPC and are listed in Table 3. Examination of the tensile strength revealed that the tensile strength (Figure 11) of the electrospun PVA nanofibers is similar to that of the fully saponified PVA nanofibers. The results of the molecular weight determination and the tensile strength analysis indicated that the mechanical properties of fully saponified PVAc nanofibers do not deteriorate as a result of the heterogeneous saponification process. 

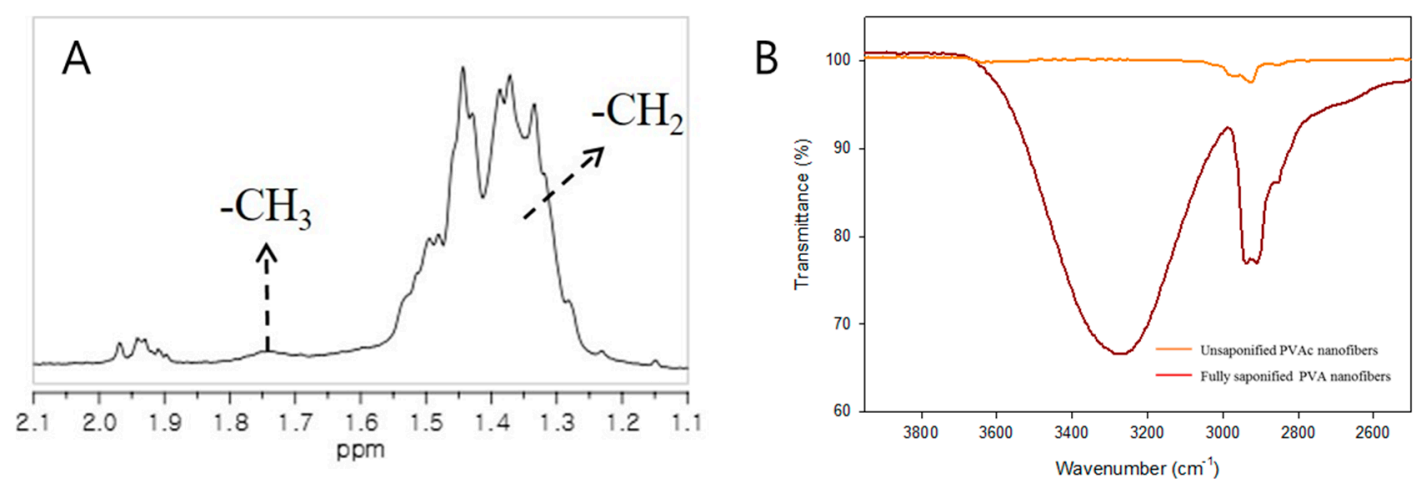

Figure 10. (A) A partial proton nuclear magnetic resonance spectrum of fully saponified PVA nanofibers; (B) Partial Fourier transform infrared spectroscopy spectra for un-saponified PVAc nanofibers (orange) and fully saponified PVA nanofibers (red). The polymer concentration was kept constant at $15 \mathrm{wt} \%$ and the saponification solution was comprised of $\mathrm{NaOH}(10 \mathrm{~g}), \mathrm{Na}_{2} \mathrm{SO}_{4}(10 \mathrm{~g})$, $\mathrm{MeOH}(10 \mathrm{~g})$, and $\mathrm{H}_{2} \mathrm{O}(100 \mathrm{~g})$. The saponification temperature was $25^{\circ} \mathrm{C}$, the saponification time was $30 \mathrm{~h}$, and DS was $99.93 \%$.

Table 3. Molecular weights of generally electrospun PVA nanofibers and saponified PVA nanofibers with DS of $99.9 \%$ [24], as determined by gel permeation chromatography.

\begin{tabular}{cccc}
\hline Sample & $\boldsymbol{M}_{\mathrm{w}}(\mathrm{g} / \mathrm{mol})$ & $\boldsymbol{M}_{\mathrm{n}}(\mathrm{g} / \mathrm{mol})$ & Polydispersity index $\left(\boldsymbol{M}_{\mathrm{w}} / \boldsymbol{M}_{\mathbf{n}}\right)$ \\
\hline $\begin{array}{c}\text { General PVA nanofibers } \\
\text { Saponified PVA } \\
\text { nanofibers }\end{array}$ & 82,125 & 10,841 & 7.57 \\
\hline
\end{tabular}

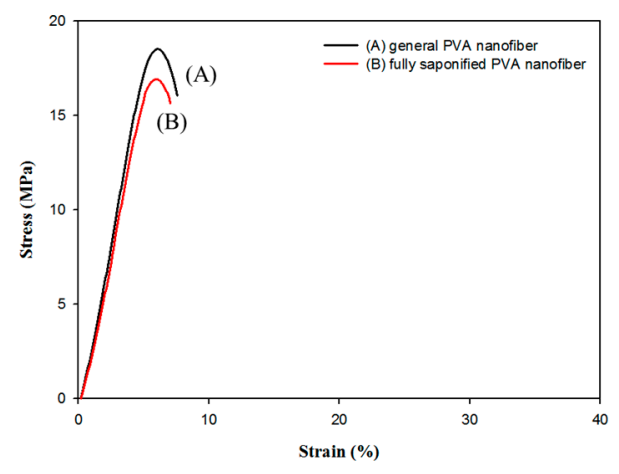

Figure 11. Stress-strain curve of: (A) general electrospun PVA nanofibers; and (B) fully saponified PVA nanofibers formed by heterogeneous saponification of electrospun PVAc nanofibers. The concentration of these nanofibers was at $15 \mathrm{wt} \%$ and the saponification solution was prepared using $\mathrm{NaOH}(10 \mathrm{~g})$, $\mathrm{Na}_{2} \mathrm{SO}_{4}(10 \mathrm{~g}), \mathrm{MeOH}(10 \mathrm{~g})$ and $\mathrm{H}_{2} \mathrm{O}(100 \mathrm{~g})$. The saponification temperature and time were $25^{\circ} \mathrm{C}$ and $30 \mathrm{~h}$, respectively. The DS value of the fully saponified nanofibers was $99.93 \%$.

\section{Conclusions}

In this study, completely saponified PVA nanofiber mats were obtained successfully through heterogeneous saponification of PVAc nanofibers, and the effect of saponification conditions, including temperature, saponification time, and the alkaline solution concentration on the morphology of the fabricated PVA nanofibers was evaluated. The obtained FESEM images demonstrated that the resulting fiber diameter decreases with increasing saponification time and temperature, while varying the concentration of the alkaline solution affected both the fiber diameter and morphology. In addition, the DS of PVA nanofibers was also found to depend on the saponification time, temperature, and alkaline solution concentration. The most optimal saponification conditions for the fabrication of thin, 
uniform, and smooth PVA nanofibers were found to correspond to an alkaline solution containing $10 \mathrm{~g}$ each of $\mathrm{NaOH}, \mathrm{Na}_{2} \mathrm{SO}_{4}$, and $\mathrm{MeOH}$ per $100 \mathrm{~g}$ of $\mathrm{H}_{2} \mathrm{O}$, a temperature of $25^{\circ} \mathrm{C}$, and a saponification time of $24 \mathrm{~h}$.

Acknowledgments: This research study was supported by the Technology Commercialization Support Program (113042-3) funded by the Ministry of Agriculture, Food, and Rural Affairs of Korea. In addition, this work was partially supported by the Human Resource Training Program for Regional Innovation and Creativity through the Ministry of Education and the National Research Foundation of Korea (Grant No. 2015H1C1A1035576).

Author Contributions: Seong Baek Yang carried out the experimental study and wrote the manuscript; Jong Won Kim design of study and carried out the conception; and Jeong Hyun Yeum supervised the research.

Conflicts of Interest: The authors declare no conflict of interest.

\section{References}

1. Sakurada, I. Polyvinyl Alcohol Fibers; Dekker: New York, NY, USA, 1985.

2. Masuda, M. Polyminyl Alcohol-Development; Wiley: New York, NY, USA, 1991.

3. Lyoo, W.S.; Ha, W.S. Structure and properties of microfibrillar poly(vinyl alcohol) fibres prepared by saponification under shearing force of poly(vinyl pivalate). Polymer 1996, 37, 3121-3129. [CrossRef]

4. Lyoo, W.S.; Blackwell, J.; Ghim, H.D. Structure of poly(vinyl alcohol) microfibrils produced by saponification of copoly(vinyl pivalate/vinyl acetate). Macromolecules 1998, 31, 4253-4259. [CrossRef]

5. Lyoo, W.S.; Ha, W.S. In situ fibrillation of poly(vinyl alcohol) during saponification of poly(vinyl ester) (1). Chemorheological and morphological investigations of in situ fibrillation. Polymer 1999, 40, 497-505. [CrossRef]

6. Taepaiboon, P.; Rungsardthong, U.; Supaphol, P. Drug-loaded electrospun mats of poly(vinyl alcohol) fibres and their release characteristics of four model drugs. Nanotechnology 2006, 17, 2317-2329. [CrossRef]

7. Zeng, J.; Aigner, A.; Czubayko, F.; Kisse, T.; Wendorff, J.H.; Greiner, A. Poly(vinyl alcohol) nanofibers by electrospinning as a protein delivery system and the retardation of enzyme release by additional polymer coatings. Biomacromolecules 2005, 6, 1484-1488. [CrossRef] [PubMed]

8. Park, J.H.; Karim, M.R.; Kim, I.K.; Cheong, I.W.; Kim, J.W.; Bae, D.G. Electrospinning fabrication and characterization of poly(vinyl alcohol)/montmorillonite/silver hybrid nanofibers for antibacterial applications. Colloid Polym. Sci. 2010, 288, 115-121. [CrossRef]

9. Shalumon, K.T.; Binulal, N.S.; Selvamurugan, N.; Nair, S.V.; Menon, D.; Furuike, T. Electrospinning of carboxymethyl chitin/poly(vinyl alcohol) nanofibrous scaffolds for tissue engineering applications. Carbohydr. Polym. 2009, 77, 863-869. [CrossRef]

10. Jia, Y.T.; Gong, J.; Gu, X.H.; Kim, H.Y.; Dong, J.; Shen, X.Y. Fabrication and characterization of poly (vinyl alcohol)/chitosan blend nanofibers produced by electrospinning method. Carbohydr. Polym. 2007, 67, 403-409. [CrossRef]

11. Lee, S.G.; Kim, J.P.; Kwon, I.C.; Park, K.H.; Noh, S.K.; Han, S.S. Heterogeneous surface saponification of suspension-polymerized monodisperse poly(vinyl acetate) microspheres using various ions. J. Polym. Sci. Polym. Chem. 2006, 44, 3567-3576. [CrossRef]

12. Lee, S.G.; Kim, J.P.; Lyoo, W.S.; Kwak, J.W.; Noh, S.K.; Park, C.S. Preparation of novel syndiotactic poly(vinyl alcohol) microspheres through the low-temperature suspension copolymerization of vinyl pivalate and vinyl acetate and heterogeneous saponification. J. Appl. Polym. Sci. 2005, 95, 1539-1548. [CrossRef]

13. Lyoo, W.S.; Lee, H.W. Synthesis of high-molecular-weight poly(vinyl alcohol) with high yield by novel one-batch suspension polymerization of vinyl acetate and saponification. Colloid Polym. Sci. 2002, 280, $835-840$.

14. Lyoo, W.S.; Kwak, J.W.; Choi, K.H.; Noh, S.K. Preparation of high molecular weight poly(vinyl alcohol) with high yield by emulsion polymerization of vinyl acetate using 2,2'-azobis(2-amidinopropane) dihydrochloride. J. Appl. Polym. Sci. 2004, 94, 2356-2362. [CrossRef]

15. Jung, H.M.; Lee, E.M.; Ji, B.C.; Deng, Y.; Yun, J.D.; Yeum, J.H. Poly(vinyl acetate)/poly(vinyl alcohol)/ montmorillonite nanocomposite microspheres prepared by suspension polymerization and saponification. Colloid Polym. Sci. 2007, 285, 705-710. [CrossRef]

16. Yeum, J.H. Novel Poly(vinyl alcohol)/Clay Nanocomposite Microspheres via suspension polymerization and saponification. Polym. Plast. Technol. Eng. 2011, 50, 1149-1154. [CrossRef] 
17. Bai, J.; Li, Y.; Yang, S.; Du, J.; Wang, S.; Zheng, J. A simple and effective route for the preparation of poly(vinylalcohol) (PVA) nanofibers containing gold nanoparticles by electrospinning method. Solid State Commun. 2007, 141, 292-295. [CrossRef]

18. Jeong, J.S.; Moon, J.S.; Jeon, S.Y.; Park, J.H.; Alegaonkar, P.S.; Yoo, J.B. Mechanical properties of electrospun PVA/MWNTs composite nanofibers. Thin Solid Films 2007, 515, 5136-5141. [CrossRef]

19. Koski, A.; Yim, K.; Shivkumar, S. Effect of molecular weight on fibrous PVA produced by electrospinning. Mater. Lett. 2004, 58, 493-497. [CrossRef]

20. Zhang, C.; Yuan, X.; Wu, L.; Han, Y.; Sheng, J. Study on morphology of electrospun poly(vinyl alcohol) mats. Eur. Polym. J. 2005, 41, 423-432. [CrossRef]

21. Son, W.K.; Youk, J.H.; Lee, T.S.; Park, W.H. Effect of pH on electrospinning of poly(vinyl alcohol). Mater. Lett. 2005, 59, 1571-1575.

22. Zhang, X.; Gao, X.; Jiang, L.; Zhang, X.; Qin, J. Nanofiber-modified surface directed cell migration and orientation in microsystem. Biomicrofluidics 2011, 5, 032007/1-032007/10. [CrossRef] [PubMed]

23. Zhong, J.; Zhang, H.; Yan, J.; Gong, X. Effect of nanofiber orientation of electrospun nanofibrous scaffolds on cell growth and elastin expression of muscle cells. Collids Surf. B Biointerfaces 2015, 136, 772-778. [CrossRef] [PubMed]

24. Yang, S.B.; Lee, H.J.; Sabina, Y.; Kim, J.W.; Yeum, J.H. Novel poly(vinyl alcohol) nanofibers prepared by heterogeneous saponification of electrospun poly(vinyl acetate). Colloids Surf. A Physicochem. Eng. Asp. 2016, 497, 265-270. [CrossRef]

25. Yu, Y.; Lin, C.; Yeh, J.; Lin, W. Preparation and properties of poly(vinyl alcohol)-clay nanocomposite materials. Polymer 2003, 44, 3553-3560. [CrossRef]

26. Baskaran, R.; Selvasekarapandian, S.; Hirankumar, G.; Bhuvaneswari, M.S. Dielectric and conductivity relaxations in PVAc based polymer electrolytes. Ionics 2004, 10, 129-134. [CrossRef]

27. Wu, J.; Wang, N.; Wang, L.; Dong, H.; Zhao, Y.; Jiang, L. Unidirectional water-penetration composite fibrous film via electrospinning. Soft Matter 2012, 8, 5996-5999. [CrossRef]

(C) 2016 by the authors; licensee MDPI, Basel, Switzerland. This article is an open access article distributed under the terms and conditions of the Creative Commons Attribution (CC-BY) license (http://creativecommons.org/licenses/by/4.0/). 